\title{
Potensi Abu Sekam Padi untuk Meningkatkan Ketahanan Oksidatif Non-enzimatik dan Produksi Padi Merah pada Cekaman Kekeringan
}

\author{
Possibility of Rice Husk Ash to Enhance Non-enzymatic Oxidative \\ Strength and Production of Red Rice under Drought Stress
}

\author{
Diah Rachmawati ${ }^{*}$, Ni Luh Gde Mona Monika², dan Ulfatul Masruroh ${ }^{2}$ \\ ${ }^{1}$ Laboratorium Fisiologi Tumbuhan, Fakultas Biologi \\ Universitas Gadjah Mada, Yogyakarta 55281, Indonesia \\ ${ }^{2}$ Program Pascasarjana, Program Studi Biologi, Fakultas Biologi \\ Universitas Gadjah Mada, Yogyakarta 55281, Indonesia
}

Diterima 21 Desember 2016/Disetujui 12 September 2017

\begin{abstract}
Drought inhibits several physiological process and induces oxidative stress due to the enhanced production of reactive oxygen species (ROS) mainly in photosynthetic apparatus. Silicon (Si) is known to increase tolerance of rice against drought stress. However, long period of intensive crop cultivation depleted the available soil Si by approximately 11-20\%. Rice husk ash (RHA) is potential Si source. The objective of this research was to analyze the potency of RHA through pot experiment to observe: 1) internal water balanced; 2) integrity of cell membrane and antioxidant content; and 3) production of tolerant cultivar 'Segreng' and sensitive one 'Cempo merah'. Application of RHA was at level of 0, 4, and 8 tons ha'. . Drought stress was imposed by with holding water until soil water content reached $50 \%$ of field capacity (moderate stress) and $25 \%$ of field capacity (severe stress). Application of RHA significantly increased leaf relative water content and membrane stability index of rice 'Segreng' and 'Cempo merah'. Tolerant cultivar 'Segreng' had better response than 'Cempo merah' as shown by greater leaf relative water content under moderate and severe stress. RHA application at level of 8 tons ha ${ }^{-1}$ increased index of membrane stability and level of antioxidant (AAred and $\alpha$-tocopherol) which determine production of both rice 'Segreng' and 'Cempo merah'during drought.
\end{abstract}

Keywords: antioxidant, field capacity, membrane stability, segreng cultivar, $\alpha$-tocopherol

\section{ABSTRAK}

Kekeringan menghambat berbagai proses fisiologis dan menginduksi cekaman oksidatif akibat peningkatan produksi reactive oxygen species (ROS) pada organel fotosintetik. Unsur silikon (Si) diketahui dapat meningkatkan toleransi padi (Oryza sativa L.) terhadap cekaman kekeringan. Pada lahan pertanian intensif terjadi penurunan kadar Si hingga 11-20\% sehingga diperlukan pemupukan Si. Abu sekam padi (ASP) merupakan sumber Si potensial. Penelitian bertujuan menganalisis potensi abu sekam padi sebagai sumber Si terhadap: (1) keseimbangan air internal; (2) status cekaman oksidatif dan kadar antioksidan; serta (3) produksi padi kultivar toleran Segreng dan sensitif Cempo merah selama kekeringan. Penelitian dilaksanakan di rumah kaca Jurusan Ilmu Tanah, Fakultas Pertanian UGM pada Bulan Februari-Juni 2016. Cekaman kekeringan diberikan dengan mempertahankan ketersediaan air hingga 50\% kapasitas lapang (kekeringan moderat) dan 25\% kapasitas lapang (kekeringan parah) dengan variasi dosis ASP sebesar 0, 4, dan 8 ton ha'. . Pemberian Abu sekam padi secara signifikan meningkatkan kandungan air relatif dan indeks stabilitas membran daun 'Segreng' dan 'Cempo merah'. Ketahanan padi 'Segreng' lebih baik daripada 'Cempo merah' ditunjukkan oleh kandungan air relatif daun yang lebih tinggi selama kekeringan moderat dan parah. Pemberian ASP 8 ton ha ${ }^{-1}$ meningkatkan indeks stabilitas membran dan kadar antioksidan (AAred dan $\alpha$-tokoferol) yang berkorelasi positif terhadap produksi padi 'Segreng' dan 'Cempo merah' selama kekeringan.

Kata kunci: antioksidan, kapasitas lapang, kultivar segreng, stabilitas membran, $\alpha$-tokoferol

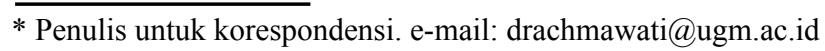




\section{PENDAHULUAN}

Keterbatasan suplai air secara signifikan mempengaruhi produktivitas padi (Barnabas et al., 2008). Hasil panen mengalami penurunan hingga $81 \%$ selama kekeringan dan dipengaruhi waktu, durasi, dan tingkat cekaman kekeringan (Zain et al., 2014). Kekeringan menyebabkan penurunan konduktansi stomata (Ji et al., 2012), laju fotosintesis (Yang et al., 2014) dan efisiensi penggunaan air (Cha-um et al., 2010).

Kekeringan menginduksi cekaman oksidatif akibat peningkatan produksi reactive oxygen species (ROS) khususnya pada organel fotosintetik (Murshe et al., 2013). Molekul ROS secara langsung dapat mengoksidasi membran lipid sehingga permeabilitas membran meningkat dan terjadi ion-leakage (Almeselmani et al., 2011). Hal ini menyebabkan penurunan indeks stabilitas membran (Liu et al., 2002; Kumar et al., 2014). Respons tumbuhan dalam meminimalisir dampak negatif ROS melalui sistem pertahanan oksidatif baik secara enzimatik maupun nonenzimatik. Peningkatan asam askorbat dan $\alpha$-tokoferol merupakan indikator respons tanaman terhadap cekaman berperan penting menjaga stabilitas membran organel fotosintetik dari oksidasi ROS selama kondisi cekaman (Szarka et al., 2012). Asam askorbat menetralkan $\mathrm{H}_{2} \mathrm{O}_{2}$ sehingga tidak mengoksidasi komponen membran lipid, sedangkan aktivitas antioksidatif $\alpha$-tokoferol berperan untuk mereduksi lipid peroxyl radical, sehingga mencegah peroksidasi lipid tak jenuh penyusun membran ( $\mathrm{Li}$ et al., 2008).

Penambahan unsur silikon (Si) meningkatkan toleransi tanaman terhadap kekeringan dengan menjaga keseimbangan air internal melalui pembentukan barier fisik, mekanik, atau terlibat dalam regulasi fisiologis. Unsur Si juga meningkatkan aktivitas pertahanan oksidatif selama kekeringan (Gunes et al., 2008). Meskipun kandungan Si tanah melimpah, ketersediaannya relatif rendah karena berada dalam bentuk kristal yang terikat dengan partikel tanah (Meena et al., 2014). Darmawan et al. (2007) melaporkan bahwa ketersediaan unsur Si di lahan pertanian Indonesia menurun sekitar 11-20\%. Penurunan kadar Si tanah ditemukan di daerah pertanian intensif yang memanen padi 2-3 kali per tahun (Husnain et al., 2008).

$\mathrm{Abu}$ sekam padi (ASP) merupakan sumber $\mathrm{Si}$ potensial. Kelarutan ASP relatif tinggi hingga mencapai 40\%-60\% dalam menyediakan bentuk $\mathrm{Si}$ yang dapat diserap tanaman (Tateda, 2016). Pemberian ASP dari limbah pembakaran batu bata dilaporkan meningkatkan pertumbuhan dan produktivitas padi dalam kondisi lingkungan optimal (Suwarto, 2015). Akan tetapi, belum pernah dilaporkan mengenai potensi ASP sebagai sumber Si terhadap peningkatan toleransi kultivar padi merah lokal selama cekaman kekeringan. Oleh karena itu, dilakukan analisis potensi ASP sebagai sumber Si terhadap ketahanan oksidatif non-enzimatik dan produksi padi kultivar toleran 'Segreng' dan sensitif 'Cempo merah' selama cekaman kekeringan.

\section{BAHAN DAN METODE}

Penelitian dilaksanakan di rumah kaca Jurusan Ilmu Tanah, Fakultas Pertanian UGM pada bulan Februari sampai dengan Juni 2016. Bahan penelitian meliputi benih padi beras merah 'Segreng' (kultivar toleran terhadap kekeringan) dari Gunung Kidul dan 'Cempo merah' (kultivar sensitif terhadap kekeringan) dari BPTP Yogyakarta; Abu sekam padi (ASP) sebagai sumber silikon ( $\mathrm{Si}$ ) mengandung $\mathrm{SiO}_{2}$ sebesar 36.28\%; Tanah bertipe geluh pasiran (sandy loam) dari Pusat Inovasi dan AgroTeknologi (PIAT) UGM.

Penelitian menggunakan Rancangan Acak Lengkap (RAL) dengan tiga faktor yaitu kultivar padi, dosis abu sekam padi dan cekaman kekeringan. Kultivar padi yang digunakan yaitu 'Segreng' dan 'Cempo merah'. Perlakuan abu sekam padi yaitu 0,4 , dan 8 ton ha ${ }^{-1}$. Perlakuan abu sekam padi diberikan pada saat sebelum tanam, dicampurkan dengan tanah dan pupuk kandang (10 ton ha $\left.\mathrm{h}^{-1}\right)$. Kondisi kekeringan dengan kapasitas lapang (KL) yang berbeda terdiri atas 3 level yaitu $100 \%, 50 \%$ dan 25\% kapasitas lapang. Masingmasing kombinasi perlakuan dengan 3 ulangan dan pada tiap polybag perlakuan ditanam 1 tanaman.

Benih disemai selama 10 hari. Kecambah dengan vigor terbaik dipindahkan ke polybag berisi $7 \mathrm{~kg}$ tanah. Penyiraman untuk mempertahankan ketersediaan air 100\% kapasitas lapang dilakukan sampai bibit berumur 7 HST (hari setelah tanam). Selanjutnya, penyiraman dikurangi hingga ketersediaan air tanah mencapai 50\% KL (kekeringan moderat) dan $25 \%$ KL (kekeringan parah). Perlakuan kekeringan dihentikan ketika 50\% tanaman kontrol telah melewati akhir fase reproduktif.

Variabel keseimbangan status air internal, status cekaman oksidatif dan kadar antioksidan (Asam askorbat tereduksi /AAred dan $\alpha$-tokoferol) diamati pada akhir fase vegetatif dan produktivitas tanaman diamati pada saat panen. Keseimbangan status air internal ditentukan dengan pengukuran kandungan air relatif daun (Hasthanasombut et al., 2010). Pengamatan status cekaman kekeringan pada daun dilakukan dengan mengukur indeks stabilitas membran melalui pengukuran ion-leakage dengan electric conductivity meter (Guo et al., 2007). Pengukuran kadar AAred mengikuti metode Ribeiro (2012) dan kadar $\alpha$ tokoferol mengikuti metode Backer et al. (1980). Karakter produksi yang diukur meliputi jumlah anakan produktif, waktu pembungaan, persentase biji bernas per malai, bobot seratus biji, dan bobot gabah total.

Data dianalisis dengan analisis sidik ragam, dilanjutkkan dengan uji DMRT dan korelasi antar parameter diukur dengan uji Pearson correlation.

\section{HASIL DAN PEMBAHASAN}

Keseimbangan Air Internal Padi 'Segreng' dan 'Cempo merah'

Kandungan air relatif (KAR) menunjukkan tingkat hidrasi daun yang dapat digunakan sebagai indikator tingkat 
cekaman yang dialami oleh tanaman saat dikondisikan pada kapasitas lapang (KL) yang berbeda. Perlakuan kekeringan berpengaruh nyata terhadap KAR daun padi 'Segreng' dan 'Cempo merah'. Nilai KAR daun padi 'Segreng' dan 'Cempo merah' pada kondisi 100\% KL tanpa penambahan ASP masing-masing sebesar 87.52\% dan $81.37 \%$ menunjukkan daun berada dalam kondisi terhidrasi optimal (Tabel 1). Pada tanaman budidaya, nilai KAR daun pada kisaran 60\%-70\% menunjukkan tanaman mengalami proses kelayuan (Zhang et al., 2015). Penurunan KAR daun kedua kultivar mulai terjadi saat kekeringan moderat. Daun padi 'Segreng' dan 'Cempo merah' mengalami kelayuan saat kekeringan parah. KAR daun Segreng pada kondisi kekeringan moderat tanpa penambahan ASP lebih tinggi dibandingkan 'Cempo merah'. Hal ini menunjukkan padi 'Segreng' lebih toleran terhadap cekaman dibandingkan 'Cempo merah'. Arjenaki et al. (2012) melaporkan kultivar gandum toleran secara signifikan memiliki persentase KAR lebih tinggi dibandingkan kultivar yang sensitif terhadap cekaman kekeringan.

Penambahan ASP pada kondisi kekeringan secara nyata meningkatkan kandungan air relatif daun padi 'Segreng' dan 'Cempo merah' (Tabel 1). Peningkatan KAR daun terjadi seiring peningkatan ketersediaan air dan dosis ASP. Penambahan ASP sebesar 8 ton ha $^{-1}$ pada kondisi kekeringan parah meningkatkan kandungan air relatif daun padi 'Segreng' dan 'Cempo merah' masing-masing $44.6 \%$ dan $23.5 \%$ lebih tinggi dibandingkan kontrol tanpa penambahan ASP. Hal ini menunjukkan ASP secara efektif meningkatkan kandungan air relatif padi 'Segreng'dan 'Cempo merah'. Ahmad and Haddad (2011) melaporkan bahwa penambahan Si dapat meningkatkan KAR pada gandum (Triticum aestivum L.) hingga 63.9\%.

\section{Indeks Stabilitas Membran (ISM)}

Pengukuran status cekaman oksidatif berdasarkan persentase ion-leakage menunjukkan indeks stabilitas membran 'Segreng' dan 'Cempo merah' pada kondisi kekeringan parah lebih rendah dibandingkan kontrol (100\% KL) (Tabel 2). Kondisi kekeringan menyebabkan penurunan indeks stabilitas membran. Hal ini karena sel yang terdehidrasi menunjukkan adanya kerusakan membran sehingga terjadi perubahan tingkat permeabilitas (Liu et al., 2002). Interaksi penambahan ASP dan kekeringan berpengaruh nyata terhadap indeks stabilitas membran. Pada kondisi 100\% kapasitas lapang penambahan ASP secara nyata meningkatkan ISM daun padi 'Segreng', namun tidak berpengaruh pada ISM daun padi 'Cempo merah' (Tabel 2). Indeks stabilitas membran daun padi 'Segreng' lebih tinggi dibandingkan 'Cempo merah' pada seluruh variasi dosis ASP. Hal ini menunjukkan bahwa

Tabel 1. Kandungan air relatif (\%) daun padi 'Segreng' dan 'Cempo merah' pada perlakuan ASP dan tingkat kekeringan

\begin{tabular}{lcccc}
\hline \multirow{2}{*}{ Kultivar } & $\begin{array}{c}\text { Cekaman kekeringan } \\
\text { (\% kapasitas lapang) }\end{array}$ & 0 & Dosis abu sekam padi (ton ha $^{-1}$ ) \\
\cline { 3 - 5 } Segreng & $100 \%$ & $87.52 \mathrm{k}$ & 4 & 97.031 \\
& $50 \%$ & $71.95 \mathrm{~d}$ & 78.371 & $80.96 \mathrm{ij}$ \\
& $25 \%$ & $53.87 \mathrm{a}$ & $75.85 \mathrm{ef}$ & $77.90 \mathrm{~g}$ \\
Cempo merah & $100 \%$ & $81.37 \mathrm{ij}$ & $82.54 \mathrm{j}$ & $88.25 \mathrm{k}$ \\
& $50 \%$ & $64.32 \mathrm{c}$ & $79.20 \mathrm{gh}$ & $78.74 \mathrm{gh}$ \\
& $25 \%$ & $61.32 \mathrm{~b}$ & $75.01 \mathrm{e}$ & $75.71 \mathrm{ef}$ \\
\hline
\end{tabular}

Keterangan: Angka-angka yang diikuti oleh huruf yang sama pada kolom dan baris yang sama menunjukkan tidak berbeda nyata berdasarkan uji DMRT pada taraf $\alpha=5 \%$

Tabel 2. Indeks stabilitas membran (\%) daun padi 'Segreng' dan 'Cempo merah' pada perlakuan ASP dan tingkat kekeringan

\begin{tabular}{lcccc}
\hline \multirow{2}{*}{ Kultivar } & $\begin{array}{c}\text { Cekaman kekeringan } \\
\text { (\% kapasitas lapang) }\end{array}$ & \multicolumn{3}{c}{${\text { Dosis abu sekam padi (ton ha }{ }^{-1} \text { ) }}$} \\
\cline { 3 - 5 } Segreng & $100 \%$ & $85.43 \mathrm{~d}$ & 4 & $89.45 \mathrm{e}$ \\
& $50 \%$ & $84.28 \mathrm{~cd}$ & $86.44 \mathrm{~d}$ & $83.99 \mathrm{~cd}$ \\
& $25 \%$ & $68.41 \mathrm{a}$ & $84.08 \mathrm{~cd}$ & $76.90 \mathrm{~b}$ \\
Cempo merah & $100 \%$ & $86.33 \mathrm{~d}$ & $68.38 \mathrm{a}$ & $85.55 \mathrm{~d}$ \\
& $50 \%$ & $84.14 \mathrm{~cd}$ & $81.69 \mathrm{c}$ & $83.33 \mathrm{~cd}$ \\
& $25 \%$ & $66.45 \mathrm{a}$ & $83.65 \mathrm{~cd}$ & $77.18 \mathrm{~b}$ \\
\hline
\end{tabular}

Keterangan: Angka-angka yang diikuti oleh huruf yang sama pada kolom dan baris yang sama menunjukkan tidak berbeda nyata berdasarkan uji DMRT pada taraf $\alpha=5 \%$ 
padi 'Segreng' lebih responsif terhadap penambahan ASP daripada 'Cempo merah'. Penambahan ASP dosis 8 ton ha' secara nyata meningkatkan indeks stabilitas membran daun padi 'Segreng' dan 'Cempo merah' pada kondisi kekeringan parah (Tabel 2). Hal ini sejalan dengan penelitian Gong et al. (2005), Si dapat meningkatkan stabilitas lipid membran pada gandum ketika dikondisikan pada kekeringan.

\section{Kadar Asam Askorbat tereduksi (AAred)}

Penambahan ASP pada media tanam meningkatkan kadar AAred daun padi 'Segreng' dan 'Cempo merah'. Pada Tabel 3 ditunjukkan peningkatan kadar AAred terjadi seiring peningkatan dosis ASP. Pemberian Si pada kondisi cekaman diketahui meningkatkan aktivitas enzim yang berperan dalam regenerasi AAred (Li et al., 2008). Penambahan ASP pada kondisi kekeringan berpengaruh nyata terhadap kadar asam askorbat tereduksi (AAred) padi 'Cempo merah' (Tabel 3). Penambahan ASP mampu meningkatkan AAred daun padi 'Cempo merah' pada 25\% kapasitas lapang. Peningkatan kadar antikosidan pada kultivar yang diberikan Si mengindikasikan cekaman oksidatif yang diinduksi oleh kekeringan berkurang karena peningkatan aktivitas ketahanan oksidatif non-enzimatik (Gong et al., 2005). Namun demikian, penambahan ASP tidak menunjukkan adanya peningkatan kadar AAred daun padi 'Segreng' pada kondisi kekeringan. Hal ini kemungkinan karena perbedaan respons ketahanan non-enzimatik pada tiap kultivar (Gunes et al., 2008).

\section{Kadar $\alpha$-tokoferol}

Perlakuan KL berpengaruh nyata terhadap kadar $\alpha$ tokoferol daun padi 'Segreng' dan 'Cempo merah'. Kadar $\alpha$-tokoferol daun 'Segreng' dan 'Cempo merah' saat kekeringan moderat tidak berbeda nyata dengan kontrol (100\% KL). Penurunan signifikan kadar $\alpha$-tokoferol daun padi 'Segreng' dan 'Cempo merah' terjadi saat kekeringan parah. Penambahan ASP secara nyata meningkatkan kadar $\alpha$-tokoferol daun padi 'Segreng' dan 'Cempo merah' (Tabel 4). Interaksi penambahan ASP dan kekeringan berpengaruh nyata terhadap kadar $\alpha$-tokoferol. Pada padi 'Segreng' dengan tingkat kekeringan parah, penambahan ASP 8 ton ha $^{-1}$ secara signifikan meningkatkan kadar $\alpha$-tokoferol dibandingkan kontrol, sedangkan pada padi 'Cempo merah' penambahan ASP tidak berpengaruh terhadap kadar $\alpha$ tokoferol (Tabel 4). Bartoli et al. (1999) melaporkan kultivar toleran menunjukkan peningkatan kadar $\alpha$-tokoferol, sementara kultivar yang sensitif mengalami penurunan total $\alpha$-tokoferol selama kondisi cekaman. Hal penelitian ini menunjukkan padi 'Segreng' lebih toleran dibandingkan 'Cempo merah'.

Tabel 3. Kadar AAred (mg g-1 BS) daun padi 'Segreng' dan 'Cempo merah' pada perlakuan ASP dan tingkat kekeringan

\begin{tabular}{|c|c|c|c|c|}
\hline \multirow{2}{*}{ Kultivar } & \multirow{2}{*}{$\begin{array}{l}\text { Cekaman kekeringan } \\
(\% \text { kapasitas lapang) }\end{array}$} & \multicolumn{3}{|c|}{ Dosis abu sekam padi (ton ha' ${ }^{-1}$ ) } \\
\hline & & 0 & 4 & 8 \\
\hline \multirow[t]{3}{*}{ Segreng } & $100 \%$ & $0.94 \mathrm{abc}$ & $1.28 \mathrm{bcde}$ & $1.58 \mathrm{efg}$ \\
\hline & $50 \%$ & $1.28 \mathrm{bcde}$ & $1.34 \mathrm{bcde}$ & $1.38 \mathrm{cdef}$ \\
\hline & $25 \%$ & $1.08 \mathrm{abcd}$ & $1.21 \mathrm{bcde}$ & $1.24 \mathrm{bcde}$ \\
\hline \multirow[t]{3}{*}{ Cempo merah } & $100 \%$ & $1.29 \mathrm{bcde}$ & $1.77 \mathrm{fg}$ & $1.92 \mathrm{f}$ \\
\hline & $50 \%$ & $0.97 \mathrm{abc}$ & $1.06 \mathrm{abcd}$ & $1.48 \mathrm{def}$ \\
\hline & $25 \%$ & $0.74 \mathrm{a}$ & $1.22 \mathrm{bcde}$ & $1.27 \mathrm{bcde}$ \\
\hline
\end{tabular}

Keterangan: Angka-angka yang diikuti oleh huruf yang sama pada kolom dan baris yang sama menunjukkan tidak berbeda nyata berdasarkan uji DMRT pada taraf $\alpha=5 \%$

Tabel 4. Kadar $\alpha$-tokoferol (mg g-1 BS) daun padi 'Segreng' dan 'Cempo merah' daun padi 'Segreng' dan 'Cempo merah' pada perlakuan ASP dan tingkat kekeringan

\begin{tabular}{lcccc}
\hline \multirow{2}{*}{ Kultivar } & $\begin{array}{c}\text { Cekaman kekeringan } \\
\text { (\% kapasitas lapang) }\end{array}$ & \multicolumn{3}{c}{${\text { Dosis abu sekam padi (ton ha }{ }^{-1} \text { ) }}^{n}$} \\
\hline Segreng & $100 \%$ & $1.65 \mathrm{~cd}$ & 4 & $1.85 \mathrm{e}$ \\
& $50 \%$ & $1.47 \mathrm{bcd}$ & $1.68 \mathrm{de}$ & $1.67 \mathrm{~cd}$ \\
& $25 \%$ & $1.23 \mathrm{ab}$ & $1.60 \mathrm{~cd}$ & $1.60 \mathrm{~cd}$ \\
Cempo merah & $100 \%$ & $1.43 \mathrm{bc}$ & $1.34 \mathrm{abcd}$ & $1.63 \mathrm{~cd}$ \\
& $50 \%$ & $1.18 \mathrm{ab}$ & $1.61 \mathrm{~cd}$ & $1.45 \mathrm{bc}$ \\
\hline
\end{tabular}

Keterangan: Angka-angka yang diikuti oleh huruf yang sama pada kolom dan baris yang sama menunjukkan tidak berbeda nyata berdasarkan uji DMRT pada taraf $\alpha=5 \%$ 
Tabel 5. Korelasi antar parameter status cekaman dan kadar antioksidan padi 'Segreng' dan 'Cempo merah'

\begin{tabular}{lccc}
\hline Kultivar & & ISM & [AAred] \\
\hline 'Segreng' & [AAred] & 0.167 ts & \\
& {$[\alpha$-tok] } & $0.579^{* *}$ & $0.550^{* *}$ \\
'Cempo merah' & {$[$ AAred] } & $0.445^{*}$ & \\
& {$[\alpha$-tok] } & $0.432^{*}$ & $0.719^{* *}$ \\
\hline
\end{tabular}

Keterangan: Pearson correlation test: ts = tidak signifikan; $*=$ signifikan pada $\mathrm{p}<0.05 ; * *=$ signifikan pada $\mathrm{p}<0.01$; ISM = Indeks stabilitas membran; AAred $=$ Asam askorbat tereduksi; $\alpha$-tok: $\alpha$-tokoferol

Tabel 5 menunjukkan korelasi antar indeks stabilitas membran dan kadar antioksidan (AAred dan $\alpha$-tokoferol) padi 'Segreng' dan 'Cempo merah'. Kadar a-tokoferol berkorelasi sangat signifikan dengan kadar asam askorbat daun 'Segreng' dan 'Cempo merah'. Peningkatan biosintesis $\alpha$-tokoferol sebagai bentuk perlindungan terhadap organel fotosintetik (Li et al., 2008). Hal ini berkaitan dengan fungsi utama $\alpha$-tokoferol dalam mereduksi singlet oksigen $\left(\mathrm{O}_{1}^{2}\right)$ dan radikal hidroxyl $\left(\mathrm{OH}^{-}\right)$pada membran fotosintetik serta menghambat peroksidasi lipid membran seluler. Selain itu, $\alpha$-tokoferol juga melindungi gugus hidrosulfida pada protein dari oksidasi oleh molekul ROS (Li et al., 2008). Oleh karena itu, kadar $\alpha$-tokoferol berkorelasi signifikan terhadap indeks stabilitas membran padi 'Segreng' dan 'Cempo merah'.

\section{Produksi Padi 'Segreng'dan 'Cempo merah'}

Kekeringan merupakan faktor pembatas produksi tanaman. Penambahan ASP sebagai sumber Si meningkatkan produksi padi 'Segreng dan 'Cempo merah'. Hasil penelitian ini menunjukkan jumlah anakan produktif dipengaruhi secara nyata oleh interaksi penambahan ASP dan tingkat kekeringan baik pada padi 'Segreng' maupun 'Cempo merah' (Tabel 6). Hal ini menunjukkan bahwa ASP memiliki peran penting pada pembentukan jumlah anakan produktif padi 'Segreng' dan 'Cempo merah' pada kondisi kekeringan. Pada kondisi kekeringan moderat dan parah, penambahan
ASP berpengaruh nyata meningkatkan jumlah anakan padi 'Segreng' maupun 'Cempo merah'. Penambahan ASP dosis 8 ton ha $^{-1}$ secara signifikan meningkatkan jumlah anakan padi 'Segreng' dan 'Cempo merah' pada kondisi kekeringan moderat dan parah. Gunes et al. (2008) melaporkan bahwa pemberian $\mathrm{Si}$ mampu meningkatkan toleransi terhadap kekeringan.

Tingkat kekeringan juga berpengaruh nyata menunda waktu pembungaan padi 'Segreng' maupun 'Cempo merah'. Waktu pembungaan padi 'Segreng' dan 'Cempo merah' semakin lama seiring dengan menurunnya ketersediaan air. Pada kondisi 25\% kapasitas lapang terjadi penundaan waktu berbunga pada 'Segreng' dan 'Cempo merah'. Penundaan waktu berbunga menunjukkan adanya hambatan pertumbuhan dan indikator kerentanan tanaman terhadap cekaman kekeringan (Tubur et al., 2012). Namun pemberian ASP berpengaruh nyata mempercepat waktu pembungaan padi 'Segreng' maupun 'Cempo merah'. Waktu munculnya bunga terjadi lebih cepat seiring berkurangnya status cekaman karena penambahan ASP (Tabel 7). Penambahan ASP 8 ton ha $^{-1}$ pada $25 \%$ kapasitas lapang mempercepat pembungaan padi 'Segreng' dan 'Cempo merah' masing masing 6 dan 8 hari dibandingkan dengan kontrol. Aplikasi pupuk daun yang diekstrak dari ASP signifikan mempercepat waktu pembungaan hingga 2-3 hari dan meningkatkan produksi padi hingga 19\% (Li et al., 2014).

Penambahan ASP dan kekeringan berpengaruh nyata pada persentase biji bernas per malai (Tabel 8) dan bobot 100 biji (Tabel 9). Penambahan ASP meningkatkan persentase biji bernas padi 'Segreng' dan 'Cempo merah'. Bobot 100 biji 'Segreng' dan 'Cempo merah' meningkat secara signifikan dengan penambahan ASP pada kondisi kekeringan parah. Penambahan ASP secara nyata meningkatkan bobot gabah total padi 'Segreng' pada kondisi 100\% kapasitas lapang, namun pada kondisi 50\% kapasitas lapang penambahan ASP tidak berpengaruh.

Kekeringan berpengaruh secara nyata pada penurunan bobot gabah total padi 'Segreng dan 'Cempo merah'. Penurunan bobot gabah total seiring dengan peningkatan cekaman kekeringan. Penambahan ASP tidak berpengaruh terhadap bobot gabah total padi 'Cempo merah' pada kondisi 100\% kapasitas lapang, namun berpengaruh nyata pada peningkatan bobot gabah total padi 'Cempo merah'

Tabel 6. Jumlah anakan produktif padi 'Segreng' dan 'Cempo merah' pada perlakuan ASP dan tingkat kekeringan

\begin{tabular}{|c|c|c|c|c|}
\hline \multirow{2}{*}{ Kultivar } & \multirow{2}{*}{$\begin{array}{l}\text { Cekaman kekeringan } \\
\text { (\% kapasitas lapang) }\end{array}$} & \multicolumn{3}{|c|}{ Dosis abu sekam padi (ton ha-1) } \\
\hline & & 0 & 4 & 8 \\
\hline \multirow[t]{3}{*}{ Segreng } & $100 \%$ & $16 \mathrm{~cd}$ & $15 \mathrm{~cd}$ & $14 b c$ \\
\hline & $50 \%$ & $12 \mathrm{ab}$ & $13 \mathrm{bc}$ & $16 \mathrm{~cd}$ \\
\hline & $25 \%$ & $9 \mathrm{a}$ & $11 \mathrm{abc}$ & $15 b c$ \\
\hline \multirow[t]{3}{*}{ Cempo merah } & $100 \%$ & $17 \mathrm{e}$ & $16 \mathrm{de}$ & $12 \mathrm{abc}$ \\
\hline & $50 \%$ & $9 \mathrm{a}$ & $13 \mathrm{bc}$ & $15 \mathrm{~cd}$ \\
\hline & $25 \%$ & $9 \mathrm{a}$ & $10 \mathrm{ab}$ & $14 \mathrm{bc}$ \\
\hline
\end{tabular}

Keterangan: Angka-angka yang diikuti oleh huruf yang sama pada kolom dan baris yang sama menunjukkan tidak berbeda nyata berdasarkan uji DMRT pada taraf $\alpha=5 \%$ 
Tabel 7. Waktu pembungaan (hari) padi 'Segreng' dan 'Cempo merah' pada perlakuan ASP dan tingkat kekeringan

\begin{tabular}{lcccc}
\hline \multirow{2}{*}{ Kultivar } & $\begin{array}{c}\text { Cekaman kekeringan } \\
\text { (\% kapasitas lapang) }\end{array}$ & \multicolumn{3}{c}{${\text { Dosis abu sekam padi (ton ha }{ }^{-1} \text { ) }}$} \\
\cline { 3 - 5 } Segreng & $100 \%$ & $59 \mathrm{~b}$ & 4 & $58 \mathrm{~b}$ \\
& $50 \%$ & $64 \mathrm{~cd}$ & $61 \mathrm{bc}$ & $60 \mathrm{~b}$ \\
& $25 \%$ & $77 \mathrm{gh}$ & $76 \mathrm{gh}$ & $71 \mathrm{ef}$ \\
Cempo merah & $100 \%$ & $65 \mathrm{~d}$ & $64 \mathrm{~cd}$ & $62 \mathrm{bcd}$ \\
& $50 \%$ & $72 \mathrm{ef}$ & $72 \mathrm{ef}$ & $70 \mathrm{e}$ \\
& $25 \%$ & $83 \mathrm{i}$ & $79 \mathrm{~h}$ & $75 \mathrm{fg}$ \\
\hline
\end{tabular}

Keterangan: Angka-angka yang diikuti oleh huruf yang sama pada kolom dan baris yang sama menunjukkan tidak berbeda nyata berdasarkan uji DMRT pada taraf $\alpha=5 \%$

Tabel 8. Persentase gabah bernas per malai padi 'Segreng' dan 'Cempo merah' pada perlakuan ASP dan tingkat kekeringan

\begin{tabular}{lcccc}
\hline \multirow{2}{*}{ Kultivar } & $\begin{array}{c}\text { Cekaman kekeringan } \\
\text { (\% kapasitas lapang) }\end{array}$ & \multicolumn{3}{c}{${\text { Dosis abu sekam padi (ton ha }{ }^{-1} \text { ) }}^{2}$} \\
\hline Segreng & $100 \%$ & $81.48 \mathrm{ab}$ & 4 & $88.34 \mathrm{~b}$ \\
& $50 \%$ & $77.13 \mathrm{a}$ & $79.91 \mathrm{ab}$ & $80.88 \mathrm{ab}$ \\
& $25 \%$ & $75.86 \mathrm{a}$ & $77.06 \mathrm{a}$ & $83.46 \mathrm{ab}$ \\
Cempo merah & $100 \%$ & $84.31 \mathrm{ab}$ & $83.95 \mathrm{ab}$ & $87.93 \mathrm{~b}$ \\
& $50 \%$ & $78.28 \mathrm{ab}$ & $80.82 \mathrm{ab}$ & $84.10 \mathrm{ab}$ \\
& $25 \%$ & $69.73 \mathrm{a}$ & $71.66 \mathrm{a}$ & $83.41 \mathrm{ab}$ \\
\hline
\end{tabular}

Keterangan: Angka-angka yang diikuti oleh huruf yang sama pada kolom dan baris yang sama menunjukkan tidak berbeda nyata berdasarkan uji DMRT pada taraf $\alpha=5 \%$

Tabel 9. Bobot 100 biji (g) padi 'Segreng' dan ‘Cempo merah' pada perlakuan ASP dan tingkat kekeringan

\begin{tabular}{lcccc}
\hline \multirow{2}{*}{ Kultivar } & $\begin{array}{c}\text { Cekaman kekeringan } \\
\text { (\% kapasitas lapang) }\end{array}$ & \multicolumn{3}{c}{${\text { Dosis abu sekam padi (ton ha }{ }^{-1} \text { ) }}$} \\
\cline { 3 - 5 } Segreng & $100 \%$ & $2.18 \mathrm{fgh}$ & 4 & $2.48 \mathrm{i}$ \\
& $50 \%$ & $2.10 \mathrm{defg}$ & $2.26 \mathrm{hi}$ & $2.21 \mathrm{gh}$ \\
& $25 \%$ & $1.89 \mathrm{bc}$ & $2.13 \mathrm{fgh}$ & $2.06 \mathrm{def}$ \\
Cempo merah & $100 \%$ & $2.12 \mathrm{efg}$ & $2.01 \mathrm{de}$ & $2.36 \mathrm{ij}$ \\
& $50 \%$ & $2.09 \mathrm{defg}$ & $2.15 \mathrm{fgh}$ & $2.17 \mathrm{fgh}$ \\
& $25 \%$ & $1.75 \mathrm{a}$ & $2.15 \mathrm{fgh}$ & $1.98 \mathrm{~cd}$ \\
\hline
\end{tabular}

Keterangan: Angka-angka yang diikuti oleh huruf yang sama pada kolom dan baris yang sama menunjukkan tidak berbeda nyata berdasarkan uji DMRT pada taraf $\alpha=5 \%$

pada kondisi kekeringan moderat. Hal ini berkaitan dengan perbedaan respons tanaman terhadap penyerapan unsur hara yang berhubungan dengan ketersediaan air.

Bobot gabah total kultivar toleran 'Segreng' lebih rendah dibandingkan 'Cempo merah' diindikasikan karena perbedaan tingkat ekspresi gen yang meregulasi karakter malai. Bobot gabah total per tanaman 'Segreng' dan 'Cempo merah' paling tinggi pada pemberian ASP dengan dosis 8 ton ha $^{-1}$ (Tabel 10). Pengaruh Si terhadap bobot gabah total per tanaman merupakan akumulasi peran Si dalam meningkatkan efisiensi penyerapan air dan hara, mempertahankan laju fotosintesis (Gerami et al., 2012), serta meminimalisir kerusakan membran oleh ROS selama cekaman kekeringan (Gong et al., 2005). Hasil menunjukkan bahwa pada kondisi kekeringan parah pengaruh penambahan ASP lebih efektif pada kultivar Segreng daripada Cempo merah. Hal ini berkaitan dengan ketahanan tanaman padi 'Cempo merah' yang merupakan kultivar sensitif kekeringan.

Tabel 11 menunjukkan korelasi antara indeks stabilitas membran terhadap produktivitas 'Segreng' dan 'Cempo merah'. Penambahan ASP meningkatkan indeks stabilitas membran. Stabilitas membran penting untuk melangsungkan 
Tabel 10. Bobot gabah total (g) padi 'Segreng' dan 'Cempo merah' pada perlakuan ASP dan tingkat kekeringan

\begin{tabular}{lcccc}
\hline \multirow{2}{*}{ Kultivar } & $\begin{array}{c}\text { Cekaman kekeringan } \\
\text { (\% kapasitas lapang) }\end{array}$ & \multicolumn{3}{c}{${\text { Dosis abu sekam padi (ton ha }{ }^{-1} \text { ) }}$} \\
\cline { 3 - 5 } Segreng & $100 \%$ & $30.48 \mathrm{e}$ & 4 & $40.11 \mathrm{f}$ \\
& $50 \%$ & $16.46 \mathrm{bcd}$ & $42.55 \mathrm{ef}$ & $19.45 \mathrm{~cd}$ \\
& $25 \%$ & $7.93 \mathrm{a}$ & $17.80 \mathrm{bcd}$ & $19.82 \mathrm{~cd}$ \\
Cempo merah & $100 \%$ & $47.14 \mathrm{f}$ & $13.09 \mathrm{abc}$ & $39.97 \mathrm{f}$ \\
& $50 \%$ & $15.53 \mathrm{bc}$ & $44.11 \mathrm{ef}$ & $29.73 \mathrm{e}$ \\
& $25 \%$ & $11.98 \mathrm{ab}$ & $22.77 \mathrm{~d}$ & $18.39 \mathrm{bcd}$ \\
\hline
\end{tabular}

Keterangan: Angka-angka yang diikuti oleh huruf yang sama pada kolom dan baris yang sama menunjukkan tidak berbeda nyata berdasarkan uji DMRT pada taraf $\alpha=5 \%$

Tabel 11. Korelasi antara indeks stabilitas membran dengan karakter produksi padi 'Segreng' dan 'Cempo merah'

\begin{tabular}{lcc}
\hline \multirow{2}{*}{ Karakter produksi } & \multicolumn{2}{c}{ Indeks stabilitas membran } \\
\cline { 2 - 3 } & 'Segreng' & 'Cempo merah' \\
\hline Anakan produktif & $0.400^{*}$ & $0.495^{* *}$ \\
Waktu pembungaan & $-0.864^{*}$ & $-0.813^{* *}$ \\
Persentase biji bernas & $0.402^{*}$ & $0.518^{* *}$ \\
Bobot 100 biji & $0.726^{* *}$ & $0.837^{* *}$ \\
Bobot gabah total & $0.651^{*}$ & $0.606^{* *}$ \\
\hline
\end{tabular}

Pearson correlation test $*=$ signifikan pada $\mathrm{p}<0.05 ; * *=$ signifikan pada $\mathrm{p}<0.01$

berbagai proses fisiologis yang berdampak pada pertumbuhan dan produktivitas tanaman. Indeks stabilitas membran padi 'Segreng' dan 'Cempo merah' berkorelasi positif terhadap jumlah anakan produktif, persentase gabah bernas per malai, bobot 100 biji dan bobot total gabah. Semakin tinggi tingkat stabilitas membran, jumlah anakan produktif semakin banyak, persentase gabah bernas per malai dan bobot 100 biji dan bobot total gabah semakin meningkat serta waktu pembungaan semakin cepat. Durasi fase pengisian biji dan laju mobilisasi asimilat merupakan faktor penentu bobot akhir biji (Barnabas et al., 2008). Semakin cepat waktu pembungaan (heading) dapat memaksimalkan mobilisasi asimilat sehingga terjadi peningkatan bobot biji dan jumlah biji bernas. Peningkatan jumlah anakan produktif, bobot 100 biji dan persentase biji bernas menyebabkan bobot total malai per tanaman padi 'Segreng' dan 'Cempo merah' lebih tinggi dengan pemberian ASP pada ketersediaan air berbeda.

\section{KESIMPULAN}

Abu sekam padi efektif meningkatkan ketahanan padi terhadap kekeringan. Interaksi antara ASP dan kekeringan berpengaruh nyata terhadap kandungan air relatif, indeks stabilitas membran, kadar antioksidan (AAred dan $\alpha$ tokoferol), jumlah anakan produktif, waktu pembungaan, persentase biji per malai, bobot 100 biji dan bobot gabah total. Penambahan ASP meningkatkan kadar antioksidan (AAred dan $\alpha$-tokoferol) yang berkorelasi positif terhadap produksi padi 'Segreng' dan 'Cempo merah'. Penambahan abu sekam padi lebih efektif pada padi 'Segreng' daripada 'Cempo merah' dalam meningkatkan ketahanan dan produksi pada kondisi kekeringan.

\section{UCAPAN TERIMA KASIH}

Penelitian ini dibiayai melalui skema Penelitian Fundamental Tahun 2016 dari Direktorat Riset dan Pengabdian kepada Masyarakat Direktorat Jenderal Penguatan Riset dan Pengembangan Kementerian Riset, Teknologi, dan Pendidikan Tinggi.

\section{DAFTAR PUSTAKA}

Ahmad, S.T., R. Haddad. 2011. Study of silicon effects on antioxidant enzyme activities and osmotic adjustment of wheat under drought stress. Czech J. Genet. Plant Breed. 47:17-27.

Almeselmani, M., F. Abdullah, F. Hareri, M. Naaesan, M.A. Ammar, O.Z. Kanbar, A. Saud. 2011. Effect of drought on different physiological characters and yield component in different Syrian durum wheat varieties. J. Agric. Sci. 3:127-133. 
Arjenaki, F.G., R. Jabbari, A. Morshed. 2012. Evaluation of drought stress on relative water content, chlorophyll content and mineral elements of wheat (Triticum aestivum L.) varieties. Intl. J. Agri. Crop Sci. 4:726729.

Backer, H., O. Frank, B. De Angells, S. Feingold. 1980. Plasma tocopherol in man at various times after ingesting free or ocetylaned tocopherol. Nutr. Reports Internat. 21:531-536.

Bartoli, C.G., M. Simontacchi, E. Tambussi, J. Beltrano. 1999. Drought and watering-dependent oxidative stress: Effect on antioxidant content in Triticum aestivum L. leaves. J. Exp. Bot. 50:375-383.

Barnabas, B., K. Jäger, A. Fehér. 2008. The effect of drought and heat stress on reproductive processes in cereals. Plant Cell Environ. 31:11-38.

Cha-um, S., S. Yooyongwech, K. Supaibulwatana. 2010. Water deficit stress in the reproductive stage of four indica rice (Oryza sativa L.) genotypes. Pak. J. Bot. 42:3387-3398.

Darmawan, K. Kyuma, A. Saleh, A. Subagyo, T. Masunaga, T. Wakatsuki. 2007. Effect of long-term intensive rice cultivation on the available silica content of sawah soils: Java Island, Indonesia. Soil Sci. Plant Nutr. 52:745-753.

Gong, H.J., X.Y. Zhu, K.M. Chen, S.M. Wang, C.L. Zhang. 2005. Silicon alleviates oxidative damage of wheat plants in pots under drought. Plant Sci. 169:313321 .

Gerami, M., A. Fallah, M. Khatamimoghadam. 2012. Study of potassium and sodium silicate on the morphological and chlorophyll content on the rice plant in pot experiment (Oryza sativa L.). Inter. J. Agri. Crop. Sci. 4:658-661.

Gunes, A., D.J. Pilbeam, A. Inal, S. Coban. 2008. Influence of silicon on sunflower cultivars under drought stress. I: growth, antioxidant mechanisms, and lipid peroxidation. Commun. Soil Sci. Plant Anal. 39:1885-1903.

Guo, Z., W. Ou, S. Lu, Q. Zhong. 2007. Differential responses of antioxidative system to chilling and drought in four rice cultivars differ in sensitivity. Plant Physiol. and Biochem. 44:828-836.

Hasthanasombut, S., V. Ntui, K. Supaibulwatana, M. Mii, I. Nakamura, I. 2010. Expression of indica rice OsBADH1 gene under salinity stress in transgenic tobacco. Plant Biotechnol. Rep. 4:75-83.
Husnain, T. Wakatsuki, D. Setyorini, Hermansah, K. Sato, T. Masunaga. 2008. Silica availability in soils and river water in two watersheds on Java Island, Indonesia. Soil Sci. Plant Nutr. 54:916-927.

Ji, K.X., Y.Y. Wang, W.N. Sun, Q.J. Lou, H.W. Mei, S.H. Shen, H. Chen. 2012. Drought-responsive mechanisms in rice genotypes with contrasting drought tolerance during reproductive stage. J. Plant Physiol. 169:336-344.

Kumar, S., S.K. Dwivedi, S.S. Singh, B.P. Bhatt, P. Mehta, R. Elanchezhian, V.P. Singh, O.N. Singh. 2014. Morphophysiological traits associated with reproductive stage drought tolerance of rice (Oryza sativa L.) genotypes under rain-fed condition of eastern Indo-Gangetic Plain. Ind. J. Plant Physiol. 19:87-93.

Li, Y., Z. Wang, X. Sun, K. Tang. 2008. The current opinions on the functions of tocopherol based on the genetic manipulation of tocopherol biosynthesis in plants. J. Integrative Plant Biol. 50:1057-1069.

Li, Y., G.Wang, H. Yu, W. Guo, D. Wei, X. Yan. 2014. Effects of extracted Si from rice hull ash on rice seed germination and growth. Acta Agri. Scand. Sec B Soil Plant Sci. 63:180-185.

Liu, Y., G. Fiskum, D. Schubert. 2002. Generation of reactive oxygen species by mitochondrial electron transport chain. J. Neurochem. 80:780-787.

Meena, V.D., M.L. Dotaniya, V. Coumar, S. Rajendiran, S. Kundu,A.S. Rao. 2014. A Case for silicon fertilization to improve crop yields in tropical soils. Proc. Natl. Acad. Sci. 84:505-518.

Murshe, R., L-L. Felicie, H. Sallanon. 2013. Effect of water stress on antioxydant systems and oxidative parameter in fruits of tomato (Solanum lycopersicon L, cv. Micro-tom). Physiol. Mol. Biol. Plants. 19:363378.

Ribeiro, C., J. Cambraia, P. Henrique, P. Peixoto, E. Meira, F. Júnior. 2012. Antioxidant system response induced by aluminum in two rice cultivars. Braz. J. Plant Physiol. 24:107-116.

Suwarto, J. Sutrisno, Suryono. 2015. Utilization of rice husk ash from waste brick factory as silicate fertilizer source in improving quality of paddy (rice) on rainfed land. J. Environ. Earth Sci. 5:76-79.

Szarka, A., B. Tomasskovics, G. Bánhegyi. 2012. The ascorbate-glutathione- $\alpha$-tocopherol triad in abiotic stress response. Int. J. Mol. Sci. 13:4458-4483. 
Tateda, M. 2016. Production and effectiveness of amorphous silica fertilizer from rice husks using a sustainable local energy system. J. Sci. Res. Reports. 9:1-12.

Tubur, H.W., M.A. Chozin, E. Santosa, A. Junaedi. 2012. Respon agronomi varietas padi terhadap kekeringan pada sistem sawah. J. Agron. Indonesia 40:167-173.

Yang, P.M., Q.C. Huang, Q.Y. Qin, S.P. Zhao, J.G. Zhou. 2014. Different drought-stress responses in photosynthesis and reactive oxygen metabolism between autotetraploid and diploid rice. Photosynthetica 52:193-202.
Zain, N.A.M., M.R. Ismail, M. Mahmood, A. Puteh, M.H. Ibrahim. 2014. Alleviation of water stress effects on MR220 rice by application of periodical water stress and potassium fertilization. Molecules 19:17951819.

Zhang, T., L-X. Yu, P. Zheng, Y. Li, M. Rivera, D. Main, S.L. Greene. 2015. Identification of loci associated with drought resistance traits in heterozygous autotetraploid alfalfa (Medicago sativa L.) using genome-wide association studies with genotyping by sequencing. PLOS ONE 10:1-17. 